\title{
Preferensi Masyarakat terhadap Pola Pemanfaatan Lahan Hutan Rakyat di Desa Lekopancing, Kecamatan Tanralili, Kabupaten Maros
}

\author{
Arman Syahrul Amin', Emban Ibnurusyd Mas'ud ${ }^{2},{ }^{*}$, Mas'ud Junus ${ }^{2}$ \\ ${ }^{1}$ Tim Layanan Kehutanan Masyarakat \\ 2Lab. Kebijakan dan Kewirausahaan Fakultas Kehutanan Universitas Hasanuddin \\ *E-mail: emban.masud@gmail.com
}

\begin{abstract}
This study describes the community preferences on land use arrangement in Lekopancing Village, Tanralili Subdistrict, Maros District. The results showed that the preferences of society towards the selection patterns of land use private forest determined by social factors, economic factors, and external factors. Social factors such as success stories of two persons in this village whom earn a large income from the plantation of Gmelina arborea (white teak), which is accompanied by social capital in the form of local knowledge and cultural system based on reciprocity. Economic factors, that is people felt motivated caused by increased income through the white teak plantation. External factors, such as KBR incentive programs and the provision of forestry extension worker, become the driving factors too.
\end{abstract}

Keywords: Community Forests; Land Use Patterns; Community Preferences DOI: http://dx.doi.org/10.24259/jhm.v9i2.3098

\section{PENDAHULUAN}

Umumnya, masyarakat pedesaan di Indonesia beraktifitas sebagai petani. Tersedianya lahan yang luas didalam desa, sangat memadai bagi masyarakat desa untuk bertani ataupun berkebun._Masyarakat pedesaan identik dengan istilah 'gotong-royong' yang merupakan kerja sama untuk mencapai kepentingan-kepentingan mereka (Soekanto, 2007). Maka dalam hal bertani, beternak ataupun berkebun, masyarakat desa biasanya akan membentuk sebuah kelompok tani guna berkerja secara kolektif. Dalam berkebun ataupun bertani masyarakat yang tergabung dalam satuan kelompok tani desa biasanya bercocok tanam jenis-jenis tanaman yang menjadi komoditi unggulan. Ada banyak jenis tanaman perkebunan yang bisa dikembangkan, seperti, tanaman tahunan, tanaman semusim, tumpang sari, tanaman campuran, tanaman terpencar.

Berdasarkan penelitian awal yang dilakukan pada lahan masyarakat di Desa Lekopancing, Kecamatan Tanralili, Kabupaten Maros, diketahui bahwa di masa awal 90-an, umumnya masyarakat memanfaatkan lahannya dengan menanam tanaman pertanian dan perkebunan. Kebanyakan dari tanaman tersebut adalah tanaman ubi kayu. Akan tetapi pada tahun 2010 terjadi perubahan yang signifikan pada lahan milik masyarakat tersebut. Lahan yang sebelumnya ditanami tanaman pertanian dan perkebunan telah ditanami banyak pepohonan, sehingga menyebabkan status lahan perkebunan masyarakat terkonversi menjadi sebuah kawasan hutan rakyat. Pada lahan hutan rakyat tersebut para petani memadukan tanaman kayu dengan tanaman pertanian (agroforestry) serta menerapkan pola pencampuran berbagai jenis tanaman dalam suatu lahan (mix plantation). Adapun jenis pohon yang mereka tanam berupa pohon cepat tumbuh seperti jati putih (Gmelina arborea).

Perubahan di atas mengindikasikan adanya preferensi masyarakat yang mendorong mereka mengembangkan hutan rakyat. Preferensi ini menjadi kajian penting karena dengan mengetahuinya maka dapat membantu daerah lain untuk membantu mengembangkan hutan di wilayahnya masing-masing. Implikasinya adalah persoalan lingkungan utamanya laju degradasi hutan di Indonesia dapat diminimalisir. 


\section{METODOLOGI PENELITIAN}

\subsection{Tempat dan Waktu}

Penelitian ini dilaksanakan pada Bulan Agustus 2015 hingga Bulan Maret 2016. Desa yang menjadi lokasi penelitian adalah Desa Lekopancing, Kecamatan Tanralili, Kabupaten Maros. Populasi dalam penelitian ini adalah masyarakat yang memiliki lahan hutan rakyat di Desa Lekopancing, Kecamatan Tanralili, Kabupaten Maros.

\subsection{Bahan dan Alat Penelitian}

Bahan dan alat penelitian berupa, alat tulis seperti pulpen dan kertas lembaran kuisioner, dibutuhkan untuk saat pengambilan data di lapangan dan mencatatkan keterangan masyarakat yang menjadi objek penelitian pada waktu melakukan wawancara. Serta smartphone yang dapat mendukung dokumentasi, seperti pengambilan gambar dengan fitur kameranya, dan rekaman audio dengan fitur perekam suaranya.

Pada konteks tertentu bahan dan alat yang digunakan membutuhkan kertas flipchart dan spidol untuk membantu pengaplikasian teknik pengambilan data Participatory Action Research (PAR). PAR merupakan metode pengumpulan data yang memberikan kesempatan masyarakat untuk menyusun data-datanya sendiri yang dibantu oleh peneliti selaku fasilitator (MacDonald, 2012). Adapun teknik PAR yang digunakan adalah Transect Walk, Semi-Structured Interview, Wealth Mapping, dan Social Mapping.

\subsection{Analisa Data}

Analisis data yang digunakan dalam penelitian ini adalah deskriptif kuantitatif dan deskriptif kualitatif yang dikaji secara mendalam. Hasil dari obsesrvasi langsung di lapangan akan dikaji sehingga dapat diketahui situasi-situasi yang telah terjadi sebelumnya dan temuan fakta yang dijadikan acuan untuk mengetahui perubahan terhadap pemanfaatan lahan menjadi lahan hutan rakyat. Pengamatan observatif dan wawancara tersebut dikaji dan dipahami secara bersama oleh responden yang memahami situasi sosial yang pernah terjadi. Data yang diperoleh kemudian dianalisis dan dideskripsikan secara detail.

\section{HASIL DAN PEMBAHASAN}

\subsection{Preferensi Berdasarkan Faktor Sosial}

Faktor sosial merupakan faktor dominan terhadap perubahan penggunaan lahan di lokasi penelitian. Pada tahap awal, tahun 2004, terdapat dua orang petani yang melakukan usaha rintisan berupa pengelolaan hutan rakyat. Usaha tersebut, pada tahun 2008 dan 2009, mengalami kesuksesan dengan tingkat pendapatan yang tinggi akibat penjualan kayu jati putih. Kesuksesan kedua petani tersebut kemudian menjadi viral pada skala dusun dan kemudian menyebar hingga skala desa.

Kondisi ini terjadi karena interaksi sosial yang terjadi adalah interaksi asosiatif. Interaksi ini banyak menghasilkan bentuk atau proses dalam melaksanakan aktifitas sehari-hari. Aktifitasaktifitas tersebut berupa gotong royong, saling sipakattau (saling menghormati antar sesama, baik antar sesama petani maupun dengan orang lain yang berbeda pekerjaan, gender, suku, agama dan ras), saling sipakainge' (saling mengingatkan dengan berusaha tidak menyakiti perasaan orang lain), serta saling sipakalebbi (saling menghargai dan berupaya untuk memuji serta mengangkat derajat orang lain dalam sebuah pergaulan sosial). 
Kondisi di atas diperkuat oleh sistem budaya masyarakat yang berasaskan reciprocity. Dimana melalui budaya tersebut masyarakat saling berbagi kebaikan termasuk pengalaman dengan nuansa alturisme tanpa mengharapkan imbalan, sehingga masyarakat dengan mudah mendapatkan informasi serta mengakses pengetahuan-pengetahuan dari kelompok sosialnya (Mas'ud, dkk., 2017).

Seluruh pemahaman ini divalidasi oleh masyarakat di desa lokasi penelitian. Hasil penelitian lebih lanjut mendapatkan persentase nilai $67 \%$ masyarakat terinspirasi oleh dua orang perintis pengelolaan hutan rakyat, $15 \%$ mengatakan tidak tertarik dan $18 \%$ tidak menjawab. Nilai tersebut mengindikasikan besarnya peran sebuah model yang terbukti terlaksana dan dapat memberikan hasil yang signifikan bagi pengelola. Signifikansi hasil akan dijelaskan lebih lanjut dalam preferensi berdasarkan faktor ekonomi.

Faktor pendukung lainnya dalam konteks sosial masyarakat yaitu kondisi kesiapan masyarakat dalam menerima sistem baru di wilayahnya. Sebesar $90 \%$ masyarakat di lokasi penelitian telah memiliki pengetahuan dalam mengelola lahan dengan sistem agroforestri dan terdapat $10 \%$ masyarakat belum memiliki pengetahuan. Kondisi ini berasal dari program Pemerintah Daerah melalui Dinas Kehutanan Kabupaten yang telah memberikan beragam pengalaman kepada masyarakat mulai dari konteks pembibitan, persiapan lahan hingga memelihara tanaman berkayu. Pengetahuan dan pengalaman yang telah ada memberikan kemudahan bagi para perintis pengelolaan hutan rakyat dalam menyebarkan sistem yang telah mereka laksanakan sebelumnya.

\subsection{Preferensi Berdasarkan Faktor Ekonomi}

Hasil penelitian menunjukkan bahwa penanaman jati putih dengan penerapan pola agroforestri memberi pendapatan lebih tinggi bagi masyarakat. Sistem agroforestri yang terbentuk pada lahan masyarakat adalah agroforestri sistem baris yang mengkombinasikan jenis tanaman jati putih dengan beragam tanaman semusim seperti ubi kayu, kacang mete, dan jagung.

Tabel 1. Perbandingan Pendapatan Rata-Rata Per Tahun Melalui Skema Tanaman Semusim Dengan Skema Agroforestry dalam 1 Hektar Lahan

\begin{tabular}{crr}
\hline Tahun Ke- & $\begin{array}{c}\text { Skema Kelola Lahan dengan Tanaman } \\
\text { Semusim (Rp.) }\end{array}$ & $\begin{array}{c}\text { Skema Kelola Lahan dengan Agroforestri } \\
\text { (Rp.) }\end{array}$ \\
\hline 1 & 23.220 .000 & 13.900 .000 \\
2 & 23.220 .000 & 13.900 .000 \\
3 & 23.220 .000 & 13.900 .000 \\
4 & 23.220 .000 & 13.900 .000 \\
5 & 23.220 .000 & 13.900 .000 \\
6 & 23.220 .000 & 139.000 .000 \\
\hline Jumlah & 139.320 .000 & 208.500 .000 \\
\hline Rata-Rata & 23.220 .000 & 34.750 .000 \\
\hline
\end{tabular}

Angka di atas merupakan pendapatan rata-rata masyarakat pada rata-rata lahan seluas satu hektar. Namun terdapat perbedaan dalam distribusi sebaran penerimaan pendapatan tiap tahun apabila melakukan aktifitas pengelolaan tanaman semusim dibandingkan dengan aktifitas pengelolaan dengan sistem agroforestri.

Pada konteks pengelolaan tanaman semusim penerimaan masyarakat relatif sama yaitu 23.220.000 per tahun per hektar namun pada konteks pengelolaan lahan berbasis agroforestri penerimaan terbesar terdapat pada tahun ke keenam yakni sebesar 139.000 .000 dari pendapatan sebelumnya yaitu 13.900 .000 . Nilai pada tahun ke-6 meningkat karena adanya pemanenan kayu pada lahan masyarakat. 
Melalui Tabel 1 dapat dilihat pula bahwa rasionalitas preferensi masyarakat juga terlihat jelas secara finansial. Selisih pendapatan kedua skema ini selama enam tahun (1 rotasi pengelolaan hutan rakyat) sebesar Rp.69.180.000,-.

\subsection{Preferensi Berdasarkan Faktor Eksternal}

Faktor eksternal juga memberikan pengaruh terhadap preferensi masyarakat mengembangkan hutan rakyat. Peran Dinas Kehutanan dalam pengembangan hutan rakyat di Desa Lekopancing yaitu dengan memfasilitasi masyarakat melalui petugas teknis di lapangan yang mengajarkan para petani bagaimana membibit dan merawat tanamannya, memberi peluang usaha kepada para petani di sektor kehutanan pada kegiatan temu usaha HR (Hutan Rakyat), mempertemukan pengusaha-pengusaha meubel dengan para petani, serta merincikan keuntungan dari penanaman pohon penghasil kayu yang semakin memberi dorongan kepada masyarakat dalam meningkatkan penanaman pohon pada lahan miliknya.

Kegiatan lain yang mendukung pengembangan Hutan Rakyat di Desa Lekopancing adalah Program Kebun Bibit Rajyat (KBR) yang dimulai pada tahun 2010. Berdasarkan hasil wawancara yang dilakukan, program KBR mampu memberikan stimulus bagi masyarakat dalam membangun dan mengelola Hutan Rakyat.

KBR merupakan program yang diadakan oleh kementerian kehutanan, melalui mekasnisme yang melibatkan Dinas Kehutanan Kabupaten Maros. Mekanisme tersebut sebagai berikut: Masyarakat Desa Lekopancing mengajukan satu kelompok KBR, lalu kelompok KBR bentukan desa tersebut diusulkan oleh Dinas Kehutanan Maros kepada BP DAS, kemudian BP DAS memverivikasi ke Kementerian Kehutanan, sehingga Kementerian memberi anggaran untuk menjalankan program KBR tersebut. Dampak program ini terhadap preferensi yang terlihat melalui banyaknya jati putih yang berasal dari program KBR yang dibudidayakan pada lahan masyarakat.

\section{KESIMPULAN DAN SARAN}

\subsection{Kesimpulan}

Preferensi petani di Desa Lekopancing terhadap pemilihan tanaman hutan rakyat ditentukan oleh 3 faktor, yaitu faktor sosial, faktor ekonomi, dan faktor eksternal. Pada konteks sosial, sistem altruisme para perintis pengelola hutan rakyat yang didukung oleh prinsip-prinsip gotong royong, sipakattau, sipakalebbi, dan sipakainge' menjadi penyebab preferensi masyarakat Desa Lekopancing membangun hutan rakyat. Pada konteks ekonomi, adanya contoh nilai pendapatan yang tinggi yang telah didapatkan oleh para perintis pengelola hutan rakyat menjadi stimulus bagi preferensi masyarakat. Faktor eksternal pun memberikan pengaruh penting memberikan pengaruh terhadap preferensi masyarakat karena dukungan yang diberikan oleh Dinas Kehutanan Kabupaten melalui beragam programnya mempermudah masyarakat menerima sistem hutan rakyat.

\subsection{Saran}

Pengembangan hutan rakyat perlu untuk dibantu secara intensif sehingga preferensi masyarakat tidak berubah. Hal ini membutuhkan pendampingan yang berkelanjutan baik dari pemerintah maupun lembaga swadaya masyarakat (Moeliono dkk, 2017). Selain itu kajian-kajian terkait model pengelolaan lahan yang efektif terkait pembangunan hutan rakyat perlu dilakukan dan disosialisasikan kepada masyarakat sehingga masyarakat mampu mendapatkan pendapatan yang lebih baik dari pengelolaan hutan rakyat sebelumnya. 


\section{DAFTAR PUSTAKA}

MacDonald, C. (2012). Understanding participatory action research: A qualitative research methodology option. The Canadian Journal of Action Research, 13(2), 34-50.

Mas'ud, E.I., Kadir, M. I., Molo, H., Tahnur, M., \& Hardiyanti. 2017. Potensi Pengembangan Ulat Sutera di Areal KPHP Model Awota. Jurnal Hutan dan Masyarakat, 9 (1), 17-22.

Moeliono, M., Thuy, P., Waty Bong, I., Wong, G., \& Brockhaus, M. (2017). Social Forestry - why and for whom? A comparison of policies in Vietnam and Indonesia. Forest and Society, 1(2), 78-97. doi:http://dx.doi.org/10.24259/fs.v1i2.2484

Soekanto, S. (2007). Sosiologi Suatu Pengantar. Jakarta: Raja Grafindo Persada. 